\title{
Upregulation of $\mathrm{M}_{3}$ muscarinic receptor inhibits cardiac hypertrophy induced by angiotensin II
}

\author{
Yan Liu ${ }^{1 \dagger}$, Shu Wang ${ }^{1,2+}$, Chao Wang ${ }^{1}$, Haoxin Song ${ }^{1}$, Hongmei Han', Pengzhou Hang ${ }^{1,3}$, Yanan Jiang ${ }^{1}$, \\ Lanlan $\mathrm{Wei}^{4}$, Rong Huo ${ }^{1}$, Lihua Sun ${ }^{1}, \mathrm{Xu} \mathrm{GaO}^{5}$, Yanjie Lu ${ }^{1 *}$ and Zhimin Du ${ }^{1,3^{*}}$
}

\begin{abstract}
Background: $M_{3}$ muscarinic acetylcholine receptor $\left(M_{3}-m A C h R\right)$ is stably expressed in the myocardium, but its pathophysiological role remains largely undefined. This study aimed to investigate the role of $M_{3}-m A C h R$ in cardiac hypertrophy induced by angiotensin II (Ang II) and elucidate the underlying mechanisms.

Methods: Cardiac-specific $\mathrm{M}_{3}$-mAChR overexpression transgenic (TG) mice and rat H9c2 cardiomyoblasts with ectopic expression of $\mathrm{M}_{3}$-mAChR were established. Models of cardiac hypertrophy were induced by transverse aortic constriction (TAC) or Ang II infusion in the mice in vivo, and by isoproterenol (ISO) or Ang II treatment of H9c2 cells in vitro. Cardiac hypertrophy was evaluated by electrocardiography (ECG) measurement, hemodynamic measurement and histological analysis. mRNA and protein expression were detected by real-time RT-PCR and Western blot analysis.

Results: $M_{3}-m A C h R$ was upregulated in hypertrophic heart, while $M_{2}-m A C h R$ expression did not change significantly. $\mathrm{M}_{3}$-mAChR overexpression significantly attenuated the increased expression of atrial natriuretic peptide and $\beta$-myosin heavy chain induced by Ang II both in vivo and in vitro. In addition, $\mathrm{M}_{3}-\mathrm{mAChR}$ overexpression downregulated $A T_{1}$ receptor expression and inhibited the activation of MAPK signaling in the heart.

Conclusion: The upregulation of $\mathrm{M}_{3}-\mathrm{mAChR}$ during myocardial hypertrophy could relieve the hypertrophic response provoked by Ang II, and the mechanism may involve the inhibition of MAPK signaling through the downregulation of $A T_{1}$ receptor.
\end{abstract}

Keywords: Cardiac hypertrophy, $M_{3}$ muscarinic acetylcholine receptor, Angiotensin II, Choline

\section{Background}

Heart failure is a significant cause of mortality and morbidity [1,2]. Cardiac hypertrophy is a common precursor to many forms of heart failure. Despite recent advances in the understanding of the pathogenesis of cardiac hypertrophy, currently available medications could not effectively reverse pathologic cardiac hypertrophy. Therefore, the identification of novel therapeutic targets for cardiac hypertrophy is pivotal for the development of effective treatment strategies. Sympathetic and parasympathetic divisions of the autonomic nervous systems play a major role in the regulation of cardiac function. Thus, increased attention has been

\footnotetext{
*Correspondence: yjlu86@gmail.com; dzm1956@126.com

${ }^{\dagger}$ Equal contributors

'Department of Pharmacology (State-Province key lab of China), Harbin

Medical University, Heilongjiang 150081, China

3 Institute of Clinical Pharmacology of the Second Hospital, Harbin Medical

University, Heilongjiang 150081, China

Full list of author information is available at the end of the article
}

paid to the changes in the cardiac autonomic innervation in cardiac hypertrophy and failure [3-5].

Previous studies have shown that the $\mathrm{M}_{3}$ muscarinic acetylcholine receptor $\left(\mathrm{M}_{3}-\mathrm{mAChR}\right)$ is expressed in the hearts of various species, including human, canine, guineapig and rabbit [6-8]. $\mathrm{M}_{3}$-mAChR plays important role in the regulation and maintenance of cardiac function and heart disease [9-11]. The cardiac $\mathrm{M}_{3}$-mAChR has demonstrated negative chronotropic and inotropic effects [12]. Heart rate (HR) correlates with myocardial oxygen consumption and coronary blood flow in normal and pathologic hearts. High HR is an independent predictor of total and cardiovascular mortality in patients with coronary artery disease and left ventricular systolic dysfunction $[13,14]$. Furthermore, Lamping et al. demonstrated that endothelium-dependent relaxation to acetylcholine in coronary circulation was mediated predominantly by the activation of $\mathrm{M}_{3}-\mathrm{mAChR}$ [15].

\section{Biomed Central}

(C) 2013 Liu et al.; licensee BioMed Central Ltd. This is an Open Access article distributed under the terms of the Creative Commons Attribution License (http://creativecommons.org/licenses/by/2.0), which permits unrestricted use, distribution, and reproduction in any medium, provided the original work is properly cited. 
Interestingly, the changes in the expression of $\mathrm{M}_{2}$ $\mathrm{mAChR}$ and $\mathrm{M}_{3}-\mathrm{mAChR}$ were associated with atrial dilation [16]. However, the involvement of $M_{3}-m A C h R$ in ventricular hypertrophy remains largely unexplored. Therefore, we hypothesized that cardiac $\mathrm{M}_{3}-\mathrm{mAChR}$ has potential effects on cardiac hypertrophy, in addition to improving coronary circulation and reducing HR. To test our hypothesis, we generated cardiac-specific overexpression $\mathrm{M}_{3}$-mAChR transgenic (TG) mice and rat $\mathrm{H} 9 \mathrm{c} 2$ cell line that overexpressed $\mathrm{M}_{3}-\mathrm{mAChR}$ (TG-H9c2). Using these models, we demonstrated that the upregulation of $\mathrm{M}_{3}$ $\mathrm{mAChR}$ inhibited cardiac hypertrophy induced by angiotensin II (Ang II).

\section{Materials and methods}

\section{Animals}

The animals were kept under standard animal room conditions (temperature $21 \pm 1^{\circ} \mathrm{C}$; humidity $55 \pm 5 \%$ ) with food and water unlimited. All experimental protocols were approved by the Experimental Animal Ethic Committee of Harbin Medical University, China. Use of animals followed the Guide for the Care and Use of Laboratory Animals published by the US National Institutes of Health (NIH Publication No. 85-23, revised 1996).

\section{Construction of $\mathrm{M}_{3}-\mathrm{mAChR}$ overexpression TG mice model}

TG mice were generated by using a construct in which the $\alpha$-myosin heavy chain $(\alpha-\mathrm{MHC})$ promoter drove the exclusive expression of $\mathrm{M}_{3}-\mathrm{mAChR}$ in cardiomyocytes [17]. TG mice and their wild-type (WT) littermates of either sex, 8-12 weeks old, with a body weight of 20$25 \mathrm{~g}$, were used. Age-matched WT and TG mice were randomly divided into 4 groups: (1) vehicle-infused WT mice (WT-CTRL); (2) Ang II-infused WT mice (WTAng II); (3) vehicle-infused TG mice (TG-CTRL); (4) Ang II-infused TG mice (TG-Ang II). Ang II $(0.6 \mathrm{mg} / \mathrm{kg}$ per day) or normal saline (NS) was injected subcutaneously for 14 days as described previously [18].

\section{Echocardiographic analysis}

Mice were anesthetized by intraperitoneal injection of sodium pentobarbital $(65 \mathrm{mg} / \mathrm{kg}$ ) (Sigma, St Louis, MO, USA). Then, transthoracic echocardiography was performed with an echocardiographic system equipped with a $10.0-\mathrm{MHz}$ phase-array transducer (GE Vivid 7, GE, USA). Left ventricular diameter and wall thickness were measured using $\mathrm{M}$-mode tracings as described previously [19].

\section{Hemodynamic measurements, heart weight (HW) measurement and histological analysis}

After treatment with Ang II, mice were anaesthetized by intraperitoneal injection of sodium pentobarbital (65 mg/kg), and then put on a heated platform for body temperature and electrocardiography (ECG) measurements. Pressure-volume control unit FV896B PV catheter (Scisense advancing micro-sensor technology, London, Ontario, Canada) was inserted through the right carotid artery into the aorta for mean arterial blood pressure (MAP) measurement [18]. Next, the hearts were quickly excised and washed with cold $\left(4^{\circ} \mathrm{C}\right) \mathrm{PBS}$ buffer. The ratio of whole heart weight to body weight (HW/BW) and left ventricular weight to body weight (LVW/BW) was measured. Ventricle tissue was then equally divided into three parts. One part was fixed with $4 \%$ paraformaldehyde and then stained with hematoxylin and eosin (HE). The other two parts and atrium tissues were frozen in liquid nitrogen and stored at $-80^{\circ} \mathrm{C}$ for subsequent analysis.

\section{Transverse aortic constriction}

The pressure-overload cardiac hypertrophy model was induced by transverse aortic constriction (TAC) as described previously [20]. Adult mice (BDF1, 24 \pm 2 g), were anesthetized by intraperitoneal injection of sodium pentobarbital $(65 \mathrm{mg} / \mathrm{kg})$. After successful endotracheal intubation, the cannula was connected to a volume cycled rodent ventilator (UGO BASILE S.R.L. Italy).The transverse aorta was isolated from annexed tissue, and the artery was partially ligated immediately with 7-0 silk around a 25-gauge blunted needle, which was subsequently removed. Sham operated mice underwent the same procedure, except that the transverse aorta was not partially ligated. The chest was closed and the animals were kept ventilated until the recovery of autonomic breath, and then raised for 14 days.

Preparation of neonatal rat ventricular myocytes (NRVMs) NRVMs were isolated from 1-day-old neonatal Wistar rat hearts and differentially plated to remove fibroblasts [21]. Ang II (Sigma, St Louis, MO, USA) or isoproterenol (ISO) (Sigma, St Louis, MO, USA) was added to the culture medium at a final concentration of $0.1 \mu \mathrm{M}$ or $10 \mu \mathrm{M}$ for $48 \mathrm{~h}$ to induce hypertrophy [18,22]. The cells were then harvested to determine $\mathrm{M}_{3}$-mAChR expression during cardiac hypertrophy.

\section{Construction of $\mathrm{M}_{3}-\mathrm{mAChR}$ overexpression TG-H9c2 cell model}

pcDNA3.1 (+) human $\mathrm{M}_{3}-\mathrm{mAChR}$ vector was constructed and transfected into rat $\mathrm{H} 9 \mathrm{c} 2$ cardiomyoblasts plated on BioFlex plates. After $48 \mathrm{~h}$, cells were cultured in DMEM supplemented with $10 \%(\mathrm{v} / \mathrm{v})$ heat-inactivated FBS and $500 \mu \mathrm{g} / \mathrm{mL} \mathrm{G} 418$ at $37^{\circ} \mathrm{C}$ in $5 \% \mathrm{CO}_{2}$ and $95 \%$ air, at a relative humidity of $95 \%$. The cells were split 1 to 3 at subconfluence (70\%). Before each experiment, cells were seeded at a density of $5 \times 10^{4}$ cells $/ \mathrm{cm}^{2}$. H9c2 cells were cultured in serum-free DMEM for $12 \mathrm{~h}$ before treatment with or without $0.1 \mu \mathrm{M}$ Ang II for $48 \mathrm{~h}$. To quantify the 
cell surface area, the H9c2 cells were stained with acridine orange. The relative surface area of the cells was calculated from the number of pixels by using Image-Pro Plus (version 5.0.1).

\section{Western blot analysis}

Total proteins $(\sim 60 \mu \mathrm{g})$ were extracted from cells or tissues as described previously [23], fractionated by $10 \%$ SDS-polyacrylamide gel electrophoresis and transferred to nitrocellulose membrane. The membrane was incubated at $4^{\circ} \mathrm{C}$ overnight with the primary antibodies against $\mathrm{M}_{3}$ $\mathrm{mAChR}, \mathrm{M}_{2}$-mAChR (Alomone Labs, Jerusalem, Israel); Ang II type 1 receptor ( $\mathrm{AT}_{1} \mathrm{R}$ ) (Sigma, St Louis, MO, USA); c-Jun N-terminal kinases (JNK), phospho-JNK (p-JNK), extracellular regulated protein kinase (ERK), phospho-ERK (p-ERK) and p38 mitogen-activated protein kinase (MAPK) (Santa Cruz Biotechnology, Santa Cruz, CA, USA), phospho-p38 (p-p38) (Cell Signaling
Technology, Boston, USA), followed by incubation with the secondary antibody Alexa Fluor 800 rabbit antimouse IgG $(\mathrm{H}+\mathrm{L})$ or Alexa Fluor 800 goat anti-rabbit IgG $(\mathrm{H}+\mathrm{L})$ (Invitrogen, Carlsbad, USA). The images were captured on the Odyssey Infrared Imaging System (LICOR, Upland, CA, USA) and band intensity (area $\times$ OD) was quantified using Odyssey v1.2 software with GAPDH as loading control.

\section{Real-time quantitative RT-PCR analysis}

Total RNA was extracted from the tissues using Trizol reagent (Invitrogen, USA). First-strand cDNA was synthesized by a reverse transcriptase kit (Invitrogen, USA) according to the manufacturer's instructions, and used as the template for Quatitative RT-PCR analysis on a ABI 7500 fast Real Time system (Applied Biosystems, Foster City, CA, USA), with GAPDH used as an internal control [15]. The primer sequences were as follows: GAPDH, $\mathbf{a}$
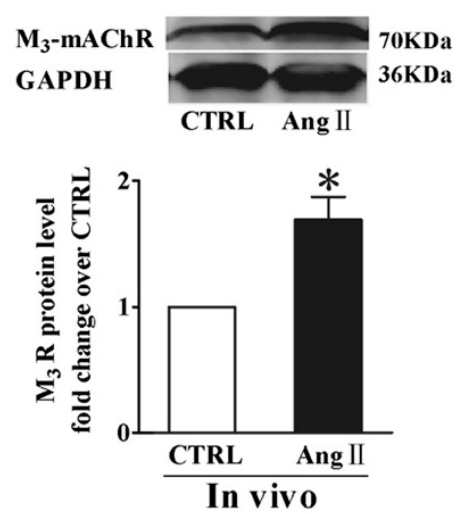

d
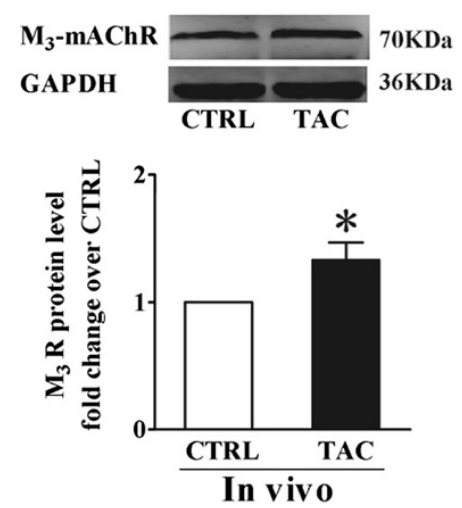

b
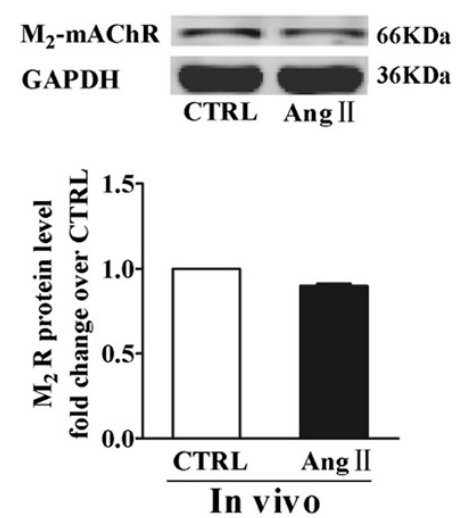

e
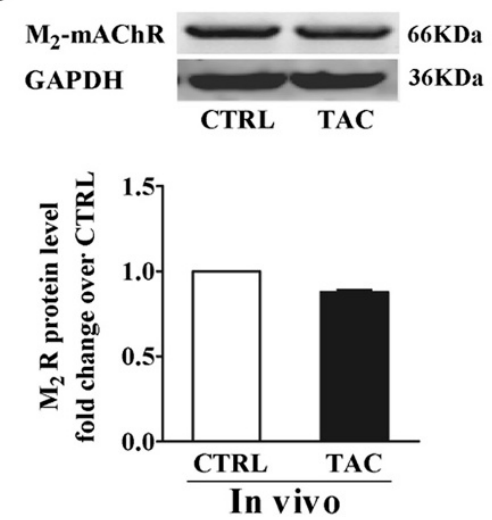
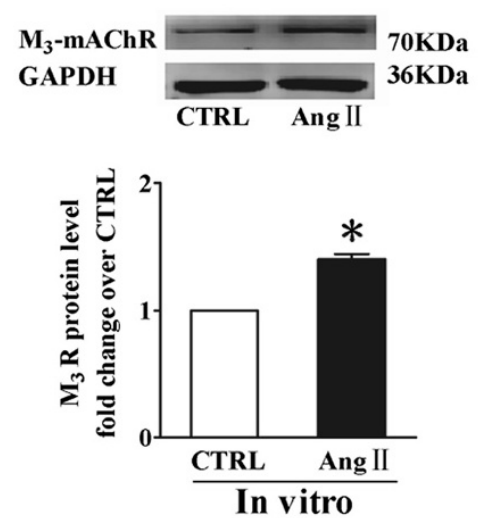

f
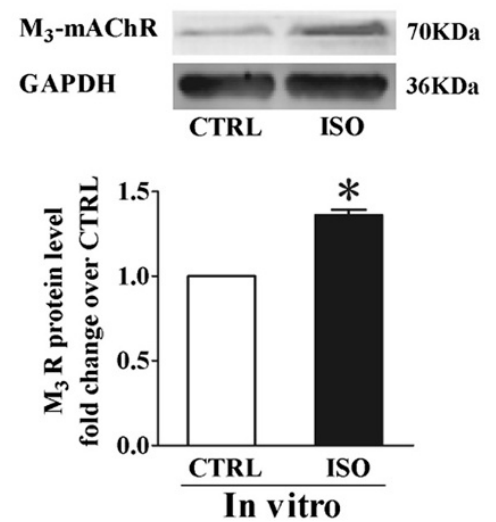

Figure 1 Upregulation of $\mathrm{M}_{3}-\mathrm{mAChR}$ expression in in vitro and in vivo models of hypertrophy. (a, b) Western blot analysis of $\mathrm{M}_{3}-\mathrm{mAChR}$ and $\mathrm{M}_{2}$-mAChR protein levels in ventricular tissues from mice with chronic angiotensin II (Ang II) ( $0.6 \mathrm{mg} / \mathrm{kg}$ per day) infusion for 14 days ( $\mathrm{n}=4$ mice per group); (c) Western blot analysis of $\mathrm{M}_{3}-\mathrm{mAChR}$ protein level in neonatal rat ventricular myocytes (NRVMs) incubated with Ang II (0.1 $\left.\mu \mathrm{M}\right)$ for 48 hours $(n=3)$; (d, e) Western blot analysis of $M_{3}-m A C h R$ and $M_{2}-m A C h R$ protein levels in ventricular tissues from mice with pressure overload by transverse aotic constriction (TAC) for 14 days ( $n=4$ mice per group); (f) $M_{3}$-mAChR protein level from NRVMs incubated with isoproterenol (ISO) $(10 \mu \mathrm{M})$ for 48 hours $(n=3)$. GAPDH served as loading control. Values were expressed as mean \pm SEM and normalized to the CTRL group. ${ }^{*} P<0.05$ vs. CTRL group. 
5' -AAGAAGGTGGTGAAGCAGGC-3' (forward), 5' TCCACCACCCTGTTGCTGTA-3' (reverse); $\beta$-myosin heavy chain $(\beta-\mathrm{MHC}), 5^{\prime}$-CCAGAAGCCTCGAAATG TC-3' (forward), 5'-CTTTCTTTGCCTTGCCTTTGC-3' (reverse); Atrial natriuretic peptide (ANP), 5'-CTCCGAT AGATCTGCCCTCTTGAA-3' (forward), 5'-GGTACCG GAAGCTGTTGCAGCCTA-3' (reverse); $\mathrm{M}_{3}$-mAChR, 5'CATCATCGGCAACATCCT-3' (forward) and 5'-GAGGT CACAGGCTAAGTTC-3' (reverse).

\section{Statistical analysis}

Data were expressed as means \pm SEM and analyzed with SPSS 13.0 software. Comparisons between two groups were made using Student's t-test. Comparisons among multiple groups were performed using analysis of variance (ANOVA) followed by Bonferroni post test. Differences were considered to be significant at $P<0.05$.

\section{Results}

Hypertrophic stimulation increases $M_{3}-m A C h R$ expression in vivo and in vitro

To assess the pathophysiological role of $\mathrm{M}_{3}-\mathrm{mAChR}$ in the heart, we first measured the $\mathrm{M}_{3}$-mAChR expression level in the ventricle during cardiac hypertrophy in vivo. We observed a $1.69 \pm 0.18$ fold increase and a $1.33 \pm 0.14$ fold increase in $M_{3}-m A C h R$ protein level in the hearts of mice after Ang II infusion or chronic pressure overload via TAC for 14 days, respectively, compared with the control (CTRL) group (Figure 1a and d). However, $\mathrm{M}_{2^{-}}$ $\mathrm{mAChR}$ protein level remained unchanged in both treatment groups (Figure $1 \mathrm{~b}$ and e). Furthermore, $\mathrm{M}_{3}-\mathrm{mAChR}$ protein level was upregulated after Ang II or isoproterenol (ISO) treatment for $48 \mathrm{~h}$ in NRVMs compared with CTRL (Ang II $1.40 \pm 0.04$; ISO $1.36 \pm 0.03$ ) (Figure 1c and f). Besides, RT-PCR analysis confirmed that Chrm3 gene expression was also upregulated in hypertrophic cardiomyocytes (Additional file 1: Figure S1). Taken together, these data suggest that $\mathrm{M}_{3}-\mathrm{mAChR}$ expression is upregulated by hypertrophy both in vivo and in vitro.

\section{$M_{3}$-mAChR overexpression exhibits anti-hypertrophic effects in $\mathrm{H} 9 \mathrm{c} 2$ cells}

To explore the biological significance of $\mathrm{M}_{3}-\mathrm{mAChR}$ expression upregulation in the heart, we compared TG-H9c2 cells with WT-H9c2 cells (Figure 2a and b). The cell surface area was significantly increased after Ang II infusion in WT-H9c2 cells compared with TGH9c2 cells (WT-Ang II $1.09 \pm 0.03$ vs. TG-Ang II $0.95 \pm 0.04$ ) (Figure 2c). In addition, the mRNA expression levels of ANP and $\beta$-MHC, which are cardiac hypertrophy-related genes, were increased by $25.76 \pm$ 6.65 and $4.53 \pm 0.43$ fold, respectively, after the incubation

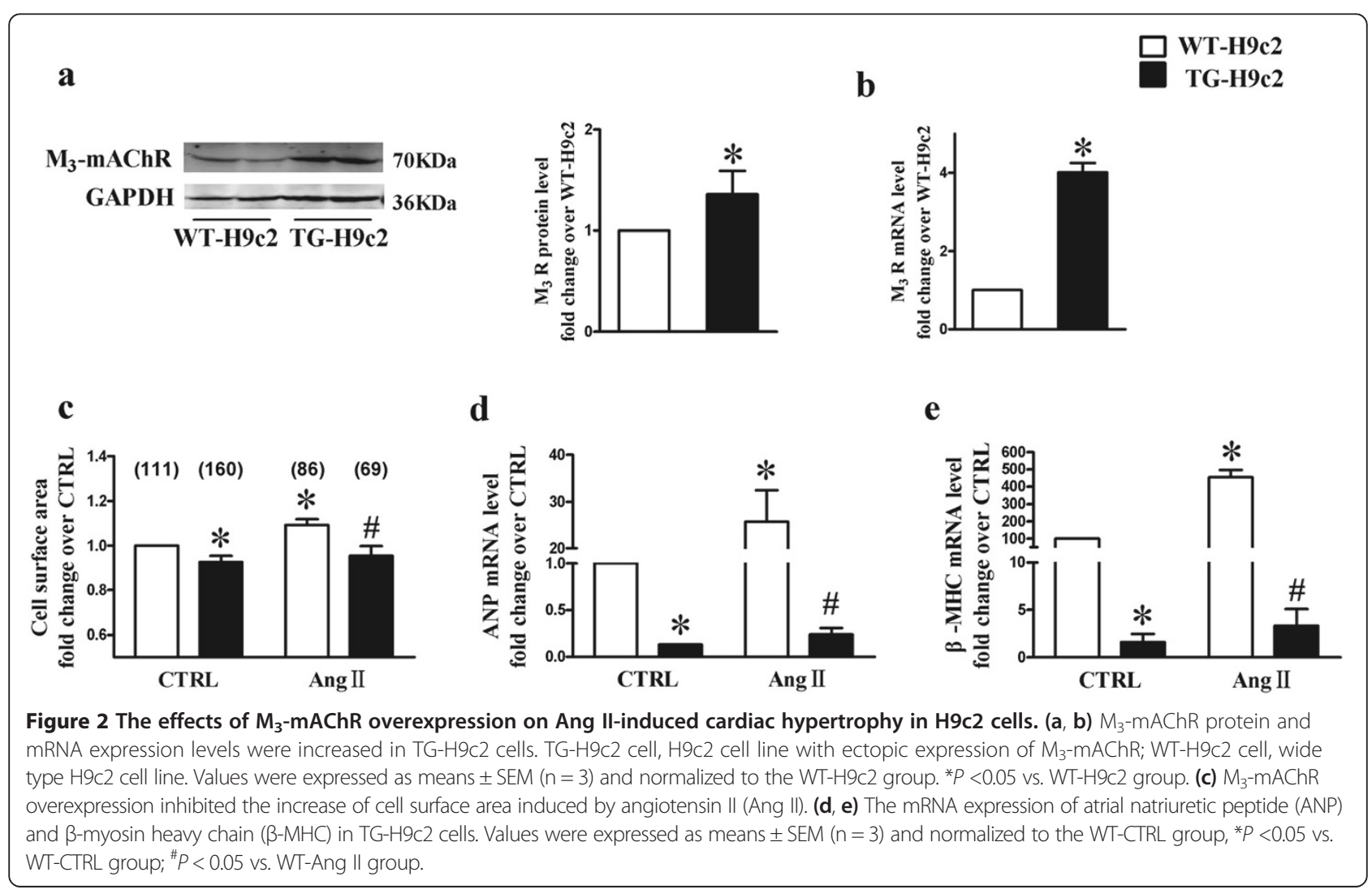


Table 1 Bodyweight (BW), heart rate (HR), mean arterial pressure (MAP), ejection fraction (EF) and echocardiographic measurements after Ang II infusion in the mice

\begin{tabular}{|c|c|c|c|c|}
\hline Variable & WT-CTRL $(n=6)$ & WT-Ang II $(n=6)$ & TG-CTRL $(n=6)$ & TG-Ang II $(n=6)$ \\
\hline BW, $g$ & $23.18 \pm 1.68$ & $20.93 \pm 1.54$ & $23.50 \pm 1.15$ & $21.30 \pm 1.05$ \\
\hline HR, bpm & $471.74 \pm 37.90$ & $642.26 \pm 45.85^{*}$ & $470.07 \pm 34.77$ & $539.20 \pm 54.83^{\#}$ \\
\hline MAP, $\mathrm{mmHg}$ & $91.54 \pm 3.94$ & $106.57 \pm 5.29^{*}$ & $99.44 \pm 4.02$ & $88.71 \pm 3.72^{\#}$ \\
\hline \multicolumn{5}{|c|}{ Echocardiography $(n=5)$} \\
\hline IVSd, mm & $0.96 \pm 0.05$ & $1.26 \pm 0.07^{*}$ & $0.86 \pm 0.05$ & $1.02 \pm 0.06^{\#}$ \\
\hline IVSs, mm & $1.38 \pm 0.06$ & $1.70 \pm 0.04^{*}$ & $1.36 \pm 0.07$ & $1.42 \pm 0.09^{\#}$ \\
\hline LVPWd, mm & $0.94 \pm 0.02$ & $1.16 \pm 0.07^{*}$ & $0.94 \pm 0.05$ & $0.90 \pm 0.04^{\#}$ \\
\hline LVPWs, mm & $1.30 \pm 0.07$ & $1.44 \pm 0.08$ & $1.24 \pm 0.04$ & $1.12 \pm 0.08^{\#}$ \\
\hline LVDd, cm & $3.24 \pm 0.32$ & $3.24 \pm 0.16$ & $3.02 \pm 0.20$ & $3.00 \pm 0.12$ \\
\hline LVDs, cm & $2.00 \pm 0.05$ & $1.84 \pm 0.04$ & $1.68 \pm 0.04$ & $1.72 \pm 0.06$ \\
\hline $\mathrm{EF}$ & $0.75 \pm 0.02$ & $0.80 \pm 0.04$ & $0.81 \pm 0.02$ & $0.77 \pm 0.08$ \\
\hline
\end{tabular}

IVSd diastolic intraventricular septum thickness, IVSs systolic intraventricular septum thickness, LVPWd diastolic left ventricular posterior wall thickness, LVPWs systolic left ventricular posterior wall thickness, $L V D d$ diastolic systolic left ventricular diameter, $L V D$ s systolic left ventricular diameter, EF ejection fraction. Values were expressed as means \pm SEM $(n=6),{ }^{*} P<0.05$ vs. WT-CTRL group; ${ }^{*} P<0.05$ vs. WT-Ang II group. WT-CTRL, vehicle-infused wild type (WT) mice; WT-Ang II, angiotensin II (Ang II)-infused WT mice; TG-CTRL, vehicle-infused transgenic (TG) mice; TG-Ang II, Ang Il-infused TG mice.

with Ang II in WT-H9c2 cells but not in TG-H9c2 cells (Figure $2 \mathrm{~d}$ and e).

\section{$M_{3}-m A C h R$ overexpression attenuates cardiac hypertrophy} induced by chronic Ang II infusion in mice

To further demonstrate the anti-hypertrophic effects of cardiac $\mathrm{M}_{3}-\mathrm{mAChR}$ in vivo, TG mice were generated with cardiac-specific overexpression of $\mathrm{M}_{3}-\mathrm{mAChR}$. As expected, Ang II infusion induced significant increases in the diastolic intraventricular septum (IVSd), systolic intraventricular septum (IVSs) and diastolic left ventricular posterior wall (LVPWd) thickness of the hearts estimated by echocardiography in WT mice. Meanwhile, HW/BW and $\mathrm{LVW} / \mathrm{BW}$ ratio, heart rate, and mean arterial pressure (MAP) were also increased (Table 1 , Figure $3 \mathrm{~b}$ and $\mathrm{c}$ ). However, the cardiac hypertrophic responses to Ang II

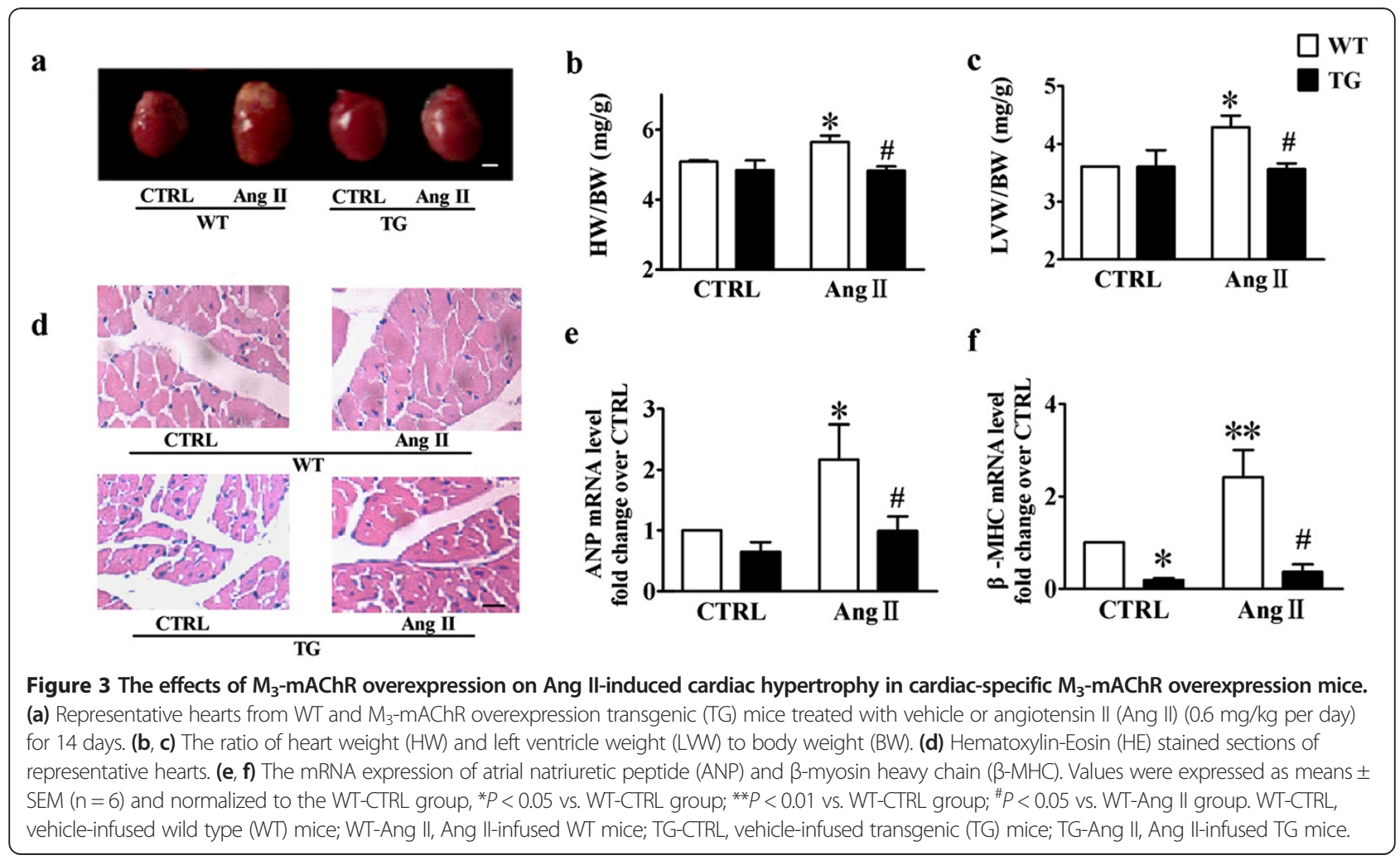


infusion were completely suppressed in TG mice (Figure 3b and $\mathrm{c}$ ). HE staining showed that $\mathrm{M}_{3}-\mathrm{mAChR}$ overexpression inhibited Ang II induced cardiomyocyte cross sectional area increase (Figure 3d, Additional file 2: Figure S2). Furthermore, real time RT-PCR analysis showed that the mRNA levels of ANP and $\beta-M H C$ were increased after Ang II infusion in WT mice compared to those in TG mice (ANP, WT-Ang II $2.17 \pm 0.58$ vs. TGAng II $0.99 \pm 0.24 ; \beta-\mathrm{MHC}$, WT- Ang II $2.42 \pm 0.59$ vs. TG- Ang II $0.36 \pm 0.16$ ) (Figure $3 e$ and $\mathrm{f}$ ). These results indicate that the cardiac hypertrophic effects induced by Ang II infusion were suppressed in TG mice with cardiacspecific overexpression of $\mathrm{M}_{3}-\mathrm{mAChR}$.

\section{$M_{3}-m A C h R$ downregulates $A T_{1} R$ expression} and the activation of MAPK signaling in TG mice

To determine the role of $\mathrm{AT}_{1} \mathrm{R}$ in the anti-hypertrophic effects mediated by $\mathrm{M}_{3}-\mathrm{mAChR}$ upregulation, we measured $\mathrm{AT}_{1} \mathrm{R}$ protein expression level in mice. Western blot analysis showed that Ang II induced the upregulation of $\mathrm{AT}_{1}$
$\mathrm{R}$ protein expression compared with CTRL in WT mice (Figure 4a). However, Ang II failed to induce the upregulation of $\mathrm{AT}_{1} \mathrm{R}$ protein expression in $\mathrm{TG}$ mice with overexpression of $\mathrm{M}_{3}-\mathrm{mAChR}$. As the downstream effector of $\mathrm{AT}_{1} \mathrm{R}$ signaling pathway, MAPK plays an important role in the development of cardiac hypertrophy [24-26]. To further explore the underlying molecular mechanism, the basal and activated levels of JNK, ERK and p38 MAPK were examined in transgenic hypertrophic mice. The levels of p-JNK, p-ERK and p-p38 MAPK were increased in WT mice after Ang II treatment (Figure $4 \mathrm{~b}$ to $\mathrm{d}$ ), indicating the activation of MAPK signaling. However, Ang II induced activation of MAPK signaling was abolished in TG mice because the levels of p-JNK, p-ERK and p-p38 MAPK were not significantly increased in these mice.

\section{Discussion}

In the present study we reported several interesting findings: (1) $\mathrm{M}_{3}-\mathrm{mAChR}$ is upregulated during Ang IIinduced cardiac hypertrophy both in vivo and in vitro;

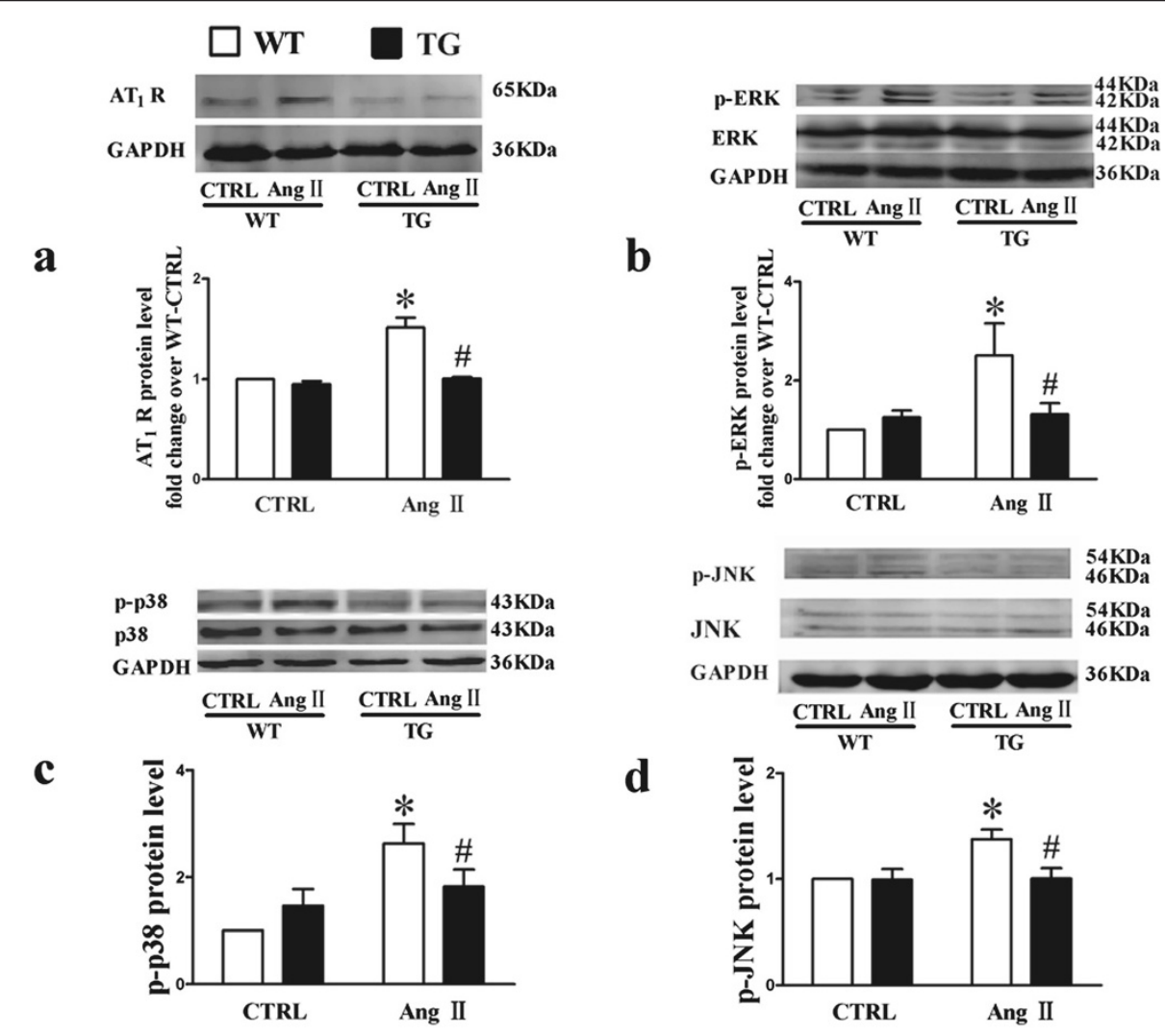

Figure 4 The changes of $\mathrm{AT}_{1} \mathrm{R}$, p-ERK1/2, p- p38-MAPK, and p-JNK levels in cardiac-specific $\mathrm{M}_{3}$-mAChR overexpression mice. (a) Western blot analysis of angiotensin II type 1 receptor (AT 1 R) protein level in WT and TG mice treated with vehicle or Ang II ( $0.6 \mathrm{mg} / \mathrm{kg}$ per day) for 14 days. The increased phospho-extracellular regulated protein kinase (p-ERK) (b), phospho-p-p38 (p-p38) level (c) and phospho- c-Jun N-terminal kinases (p-JNK) level (d) induced by angiotensin II (Ang II) infusion were attenuated in TG mice. Phospho-protein levels were relative to total protein levels, while total protein levels were relative to GAPDH. GAPDH served as loading control. Values were expressed as mean \pm SEM $(n=6)$ and normalized to the $C T R L$ group. Values were expressed as means \pm SEM. ${ }^{*} P<0.05$ vs. WT-CTRL group; ${ }^{*} P<0.05$ vs. WT-Ang II group. WT-CTRL, vehicle-infused wild type (WT) mice; WT-Ang II, Ang II -infused WT mice; TG-CTRL, vehicle-infused transgenic (TG) mice; TG-Ang II, Ang II-infused TG mice. 
(2) Upregulation of $\mathrm{M}_{3}-\mathrm{mAChR}$ could inhibit cardiac hypertrophy induced by chronic Ang II infusion; (3) Upregulation of $\mathrm{M}_{3}-\mathrm{mAChR}$ is mediated by decreased phosphorylation of ERK, JNK, and p38 MAPK cascades through the downregulation of $\mathrm{AT}_{1} \mathrm{R}$. These results provide novel insight into the mechanisms underlying the cardioprotective effects of $\mathrm{M}_{3}-\mathrm{mAChR}$ in cardiac hypertrophy, and indicate that $\mathrm{M}_{3}-\mathrm{mAChR}$ is a potential therapeutic target.

Previous studies have demonstrated that the expression of $\mathrm{M}_{3}$-mAChR is upregulated during ventricular myocardial ischemia and atrial fibrillation [10,11,27]. Similarly, in the present study, we found that the protein level of $\mathrm{M}_{3}-\mathrm{mAChR}$ was upregulated during cardiac hypertrophy both in vivo and in vitro. As a control, we detected $\mathrm{M}_{2}-\mathrm{mAChR}$ protein expression and found no significant change in hypertrophic heart. These data indicate the specific role of $\mathrm{M}_{3}-\mathrm{mAChR}$ in cardiac hypertrophy.

The activation of $\mathrm{AT}_{1} \mathrm{R}$ through the renin-angiotensin system (RAS) plays an important role in the development of cardiac hypertrophy $[28,29]$. Ang II not only regulates the vasculature, but also promotes the growth of cardiac tissues, resulting in myocardial hypertrophy independently of hypertension [26]. The antagonist of $\mathrm{AT}_{1} \mathrm{R}$ is widely used for the treatment of hypertension, and is an important drug for the prevention of cardiac remodeling after myocardial infarction. Ang II activates several intracellular signaling pathways such as MAPK signaling [25]. The p38 MAPK cascade has been shown to play a critical role in the pathogenesis of cardiac hypertrophy $[25,26,29]$. Liu et al. have demonstrated that acetylcholine prevented Ang II-induced apoptosis of $\mathrm{H} 9 \mathrm{c} 2$ cells via the downregulation of $\mathrm{AT}_{1} \mathrm{R}$, the inhibition of ROS-mediated p38 MAPK activation, as well as the regulation of $\mathrm{Bcl}-2$, Bax and caspase3 [24]. In addition, previous study showed that $\mathrm{M}_{3}-\mathrm{mAChR}$ was closely related to ERK and p38 MAPK [30]. In the present study we found that the phosphorylation levels of ERK1/2, JNK and p38 were increased in response to hypertrophic stimulation in WT mice but not in TG mice, consistent with previous studies that the p38 MAPK and ERK1/2 were involved in cardiac hypertrophy [2]. Taken together, these data suggest that MAPK signaling is crucially involved in the regulation of cardiac myocytes by $\mathrm{M}_{3}-\mathrm{mAChR}$. Suppression of the MAPK signaling by $\mathrm{M}_{3^{-}}$ $\mathrm{mAChR}$ through the downregulation of $\mathrm{AT}_{1} \mathrm{R}$ in the heart may attenuate cardiac remodeling.

It is worth mentioning that the physiological parameters, such as BW, HR, cardiac functions, and HW/BW and LVW/BW ratio, are comparable at baseline in WT and TG mice, thus the effects of cardiac-specific overexpression of $\mathrm{M}_{3}-\mathrm{mAChR}$ are likely to be exerted only in the context of hypertrophy stimulation.

In summary, the current study provides new insight into the role of $\mathrm{M}_{3}-\mathrm{mAChR}$ upregulation in the development of cardiac hypertrophy induced by Ang II. Our findings suggest that $\mathrm{M}_{3}$-mAChR functions as an endogenous negative regulator of hypertrophic response, thus representing a novel therapeutic target for cardiac hypertrophy. Additional studies to elucidate the molecular mechanisms of the anti-hypertrophic properties of cardiac $\mathrm{M}_{3}-\mathrm{mACh}$ will promote the application of $\mathrm{M}_{3}-\mathrm{mAChR}$ regulators in the clinic.

\section{Additional files}

\begin{abstract}
Additional file 1: Figure S1. Upregulation of $\mathrm{M}_{3}-m A C h R$ mRNA expression in in vitro and in vivo models of hypertrophy. (a) $M_{3}-m A C h R$ mRNA levels in ventricular tissues from mice with chronic angiotensin II (Ang II) (0.6 mg/kg per day) infusion for 14 days ( $n=4$ mice per group); (b) $\mathrm{M}_{3}-\mathrm{mAChR}$ mRNA level from neonatal rat ventricular myocytes (NRVMs) incubated with isoproterenol (ISO) $(10 \mu \mathrm{M})$ for 48 hours $(n=4)$. Values were expressed as mean \pm SEM and normalized to the CTRL group. ${ }^{*} P<0.05$ vs. CTRL group.

Additional file 2: Figure S2. $M_{3}-m A C h R$ overexpressioninhibited angiotensin II (Ang II) induced cardiomyocyte cross-sectional area increase. Values were expressed as means \pm SEM and normalized to the WT-CTRL group, ${ }^{*} P<0.05$ vs. WT-CTRL group. ${ }^{*} \mathrm{P}<0.05$ vs. WT-Ang $\|$ group. WT-CTRL, vehicle-infused wild type (WT) mice; WT-Ang II, Ang II-infused WT mice; TG-CTRL, vehicle-infused transgenic (TG) mice; TG-Ang II, Ang II-infused TG mice.
\end{abstract}

\section{Competing interests}

The authors declare they have no competing interests of this article.

\section{Authors' contributions}

$Y L$ participated in the design of the study, performed the experiments in vivo and drafted the manuscript. SW, CW, HS participated in the experiments in vitro. $\mathrm{HH}$ PH performed the statistical analysis. YJ, LW, RH, LS, XG performed real-time PCR assay. ZD conceived of the study, helped to draft the manuscript and provided supervision. YL conceived of the study, participated in its design and provided supervision. All authors read and approved the final manuscript.

\section{Acknowledgments}

We are grateful to Dr. Guoqing Du and Dr. Chunping Ning for assistance with echocardiography.

\section{Funding}

This study was supported in part by National Natural Science Foundation of China [No. 81072639] and the Funds for Creative Research Groups of The National Natural Science Foundation of China [No. 81121003].

\section{Author details}

${ }^{1}$ Department of Pharmacology (State-Province key lab of China), Harbin Medical University, Heilongjiang 150081, China. ${ }^{2}$ Department of Cardiac Care Unit, The First Affiliated Hospital of Harbin Medical University, Harbin, Heilongjiang 150081, P. R. China. Institute of Clinical Pharmacology of the Second Hospital, Harbin Medical University, Heilongjiang 150081, China. ${ }^{4}$ Department of Microbiology, Harbin, Heilongjiang 150081, P. R. China.

${ }^{5}$ Department of Biochemistry, Harbin Medical University, Harbin, Heilongjiang 150081, P. R. China.

Received: 30 April 2013 Accepted: 4 September 2013 Published: 12 September 2013

\section{References}

1. Frey N, Katus HA, Olson EN, Hill JA: Hypertrophy of the heart: a new therapeutic target? Circulation 2004, 109:1580-1589.

2. Heineke J, Molkentin JD: Regulation of cardiac hypertrophy by intracellular signaling pathways. Nat Rev Mol Cell Biol 2006, 7:589-600. 
3. Gilsbach R, Schneider J, Lother A, Schickinger S, Leemhuis J, Hein L: Sympathetic $a_{2}$-adrenoceptors prevent cardiac hypertrophy and fibrosis in mice at baseline but not after chronic pressure overload. Cardiovasc Res 2010, 86:432-442.

4. Kasama S, Toyama T, Hatori T, Sumino H, Kumakura H, Takayama Y, Ichikawa S, Suzuki T, Kurabayashi M: Evaluation of cardiac sympathetic nerve activity and left ventricular remodelling in patients with dilated cardiomyopathy on the treatment containing carvedilol. Eur Heart J 2007, 28:989-995.

5. Ohshima S, Isobe S, Izawa H, Nanasato M, Ando A, Yamada A, Yamada K, Kato TS, Obata K, Noda A, Nishizawa T, Kato K, Nagata K, Okumura K, Murohara T, Yokota M: Cardiac sympathetic dysfunction correlates with abnormal myocardial contractile reserve in dilated cardiomyopathy patients. J Am Coll Cardiol 2005, 46:2061-2068.

6. Shi H, Wang HZ, Wang ZG: Identification and characterization of multiple subtypes of muscarinic acetylcholine receptors and their physiological functions in canine hearts. Mol Pharmacol 1999, 55:497-507.

7. Wang HZ, Shi H, Lu YJ, Yang BF, Wang ZG: Pilocarpine modulates the cellular electrical properties of mammalian hearts by activating a cardiac M3 receptor and a $\mathrm{K}^{+}$current. Br J Pharmacol 1999, 126:1725-1734.

8. Wang $Z$ G, Shi $H$, Wang $H Z$ : Functional $M_{3}$ muscarinic acetylcholine receptors in mammalian hearts. Br J Pharmacol 2004, 142:395-408.

9. Liu Y, Sun HL, Li DL, Wang LY, Gao Y, Wang YP, Du ZM, Lu YJ, Yang BF: Choline produces antiarrhythmic actions in animal models by cardiac $M_{3}$ receptors: improvement of intracellular $\mathrm{Ca}^{2+}$ handling as a common mechanism. Can J Physiol Pharmacol 2008, 86:860-865.

10. Wang $S$, Han HM, Jiang YN, Wang C, Song HX, Pan ZY, Fan K, Du J, Fan YH, Du ZM, Liu Y: Activation of cardiac $M_{3}$ muscarinic acetylcholinereceptors has cardioprotective effects against ischaemia-induced arrhythmias. Clin Exp Pharmacol Physiol 2012, 39:343-349.

11. Liu Y, Du J, Gao Y, Zhang Y, Cai BZ, Zhao H, Q HP, Du ZM, Lu YJ, Yang BF: Role of $M_{3}$ receptor in aconitine/barium-chloride-induced preconditioning against arrhythmias in rats. Naunyn Schmiedebergs Arch Pharmacol 2009, 379:511-515.

12. Liu Y, Wang Y, Ma ML, Zhang Y, Li HW, Chen QW, Yang BF: Cardiac hemodynamic effects of $M_{3}$ receptor agonist on rat and rabbit hearts. Yao Xue Xue Bao 2001, 36:84-87.

13. Fox K, Ford I, Steg PG, Tendera M, Robertson M, Ferrari R: Heart rate as a prognostic risk factor in patients with coronary artery disease and leftventricular systolic dysfunction (BEAUTIFUL): a subgroup analysis of a randomized controlled trial. Lancet 2008, 372:817-821.

14. Cucherat M: Quantitative relationship between resting heart rate reduction and magnitude of clinical benefits in postmyocardial infarction: a meta-regression of randomized clinical trials. Eur Heart J 2007, 28:3012-3019.

15. Lamping KG, Wess J, Cui Y, Nuno DW, Faraci FM: Muscarinic (M) receptors in coronary circulation: gene-targeted mice define the role of $M_{2}$ and $M_{3}$ receptors in response to acetylcholine. Arterioscler Thromb Vasc Biol 2004, 24:1253-1258.

16. Zhao QY, Huang CX, Jiang $H$, Okello $E_{1}$ Tang $Y H$, Wang $Z W$, Wu ZY: $M_{2}$ and $\mathrm{M}_{3}$-muscarinic acetylcholine receptors remodeling in patients with a dilated atrium. Acta Cardiol 2008, 63:166-170.

17. Liu Y, Sun LH, Pan ZW, Bai YL, Wang N, Zhao JL, Xu CQ, Li Z, Li BX, Du ZM, Lu YJ, Gao X, Yang BF: Over-expression of $M_{3}$ muscarinic receptor is a novel strategy for preventing sudden cardiac death in transgenic mice. Mol Med 2011, 17:1179-1187.

18. Frank D, Kuhn C, van Eickels M, Gehring D, Hanselmann C, Lippl S, Will R Katus HA, Frey N: Calsarcin-1 protects against angiotensin-II induced cardiac hypertrophy. Circulation 2007, 116:2587-2596.

19. Rottman JN, Ni G, Khoo M, Wang Z, Zhang W, Anderson ME, Madu EC: Temporal changes in ventricular function assessed echocardiographically in conscious and anesthetized mice. J Am Soc Echocardiogr 2003, $16: 1150-1157$.

20. Grote-Wessels S, Baba HA, Boknik P, El-Armouche A, Fabritz L, Gillmann HJ, Kucerova D, Matus M, Müller FU, Neumann J, Schmitz M, Stümpel F, Theilmeier G, Wohlschlaeger J, Schmitz W, Kirchhefer U: Inhibition of protein phosphatase 1 by inhibitor-2 exacerbates progression of cardiac failure in a model with pressure overload. Cardiovasc Res 2008, 79:464-471.

21. Kwak BR, van Kempen MJ, Théveniau-Ruissy M, Gros DB, Jongsma HJ: Connexin expression in cultured neonatal rat myocytes reflects the pattern of the intact ventricle. Cardiovasc Res 1999, 44:370-380.
22. Tomita H, Nazmy M, Kajimoto K, Yehia G, Molina CA, Sadoshima J: Inducible CAMP early repressor (ICER) is a negative-feedback regulator of cardiac hypertrophy and an important mediator of cardiac myocyte apoptosis in response to $\beta$-adrenergic receptor stimulation. Circ Res 2003, 93:12-22.

23. Heymes C, Bendall JK, Ratajczak P, Cave AC, Samuel JL, Hasenfuss G, Shah AM: Increased myocardial NADPH oxidase activity in human heart failure. J Am Coll Cardiol 2003, 41:2164-2171.

24. Liu JJ, Li DL, Zhou J, Sun L, Zhao M, Kong SS, Wang YH, Yu XJ, Zhou J, Zang WJ: Acetylcholine prevents angiotensin Il-induced oxidative stress and apoptosis in H9c2 cells. Apoptosis 2011, 16:94-103.

25. Pellieux C, Sauthier T, Aubert JF, Brunner HR, Pedrazzini T: Angiotensin II induced cardiac hypertrophy is associated with different mitogenactivated protein kinase activation in normotensive and hypertensive mice. J Hypertens 2000, 18:1307-1317

26. Bao W, Behm DJ, Nerurkar SS, Ao Z, Bentley R, Mirabile RC, Johns DG, Woods TN, Doe CP, Coatney RW, Ohlstein JF, Douglas SA, Willette RN, Yue TL: Effects of p38 MAPK inhibitor on angiotensin II-dependent hypertension, organ damage, and superoxide anion production. J Cardiovasc Pharmacol 2007, 49:362-368.

27. Shi H, Wang H, Li D, Nattel S, Wang Z: Differential alterations of receptor densities of three muscarinic acetylcholine receptor subtypes and current densities of the corresponding $\mathrm{K}^{+}$channels in canine atria with atrial fibrillation induced by experimental congestive heart failure. Cell Physiol Biochem 2004, 14:31-40.

28. Zhai PY, Yamamoto M, Galeotti J, Liu J, Masurekar M, Thaisz J, Irie K, Holle E, Yu X, Kupershmidt S, Roden DM, Wagner T, Yatani A, Vatner DE, Vatner SF, Sadoshima J: Cardiac-specific overexpression of $\mathrm{AT}_{1}$ receptor mutant lacking $\mathrm{Gq} / \mathrm{Gi}$ coupling causes hypertrophy and bradycardia in transgenic mice. J Clin Invest 2005, 115:3045-3056.

29. Park JK, Fischer R, Dechend R, Shagdarsuren E, Gapeljuk A, Wellner M, Meiners S, Gratze P, Al-Saadi N, Feldt S, Fiebeler A, Madwed JB, Schirdewan A, Haller H, Luft FC, Muller DN: p38 mitogen-activated protein kinase inhibition ameliorates angiotensin II-induced target organ damage. Hypertension 2007, 49:481-489.

30. Luo J, Busillo JM, Benovic $J \mathrm{~L}: M_{3}$ muscarinic acetylcholine receptormediated signaling is regulated by distinct mechanisms. Mol Pharmacol 2008, 74:338-347.

doi:10.1186/1479-5876-11-209

Cite this article as: Liu et al:: Upregulation of $\mathrm{M}_{3}$ muscarinic receptor inhibits cardiac hypertrophy induced by angiotensin II. Journal of Translational Medicine 2013 11:209.

\section{Submit your next manuscript to BioMed Central and take full advantage of:}

- Convenient online submission

- Thorough peer review

- No space constraints or color figure charges

- Immediate publication on acceptance

- Inclusion in PubMed, CAS, Scopus and Google Scholar

- Research which is freely available for redistribution 